\title{
Implementation of TDP Acquired Training for Improving the Quality of Education for All
}

\author{
Umma Jummai Zakar \\ School of Education College of Arts and Sciences \\ Universiti Utara Malaysia \\ Sintok, Malaysia \\ ujzakar@gmail.comlimce89@gmail.com
}

\author{
Lim Chong Ewe \\ School of Education College of Arts and Sciences \\ Universiti Utara Malaysia \\ Sintok, Malaysia \\ ujzakar@gmail.comlimce89@gmail.com
}

\begin{abstract}
In a bid to achieve education for all the Nigerian government has embraced various initiatives that include Teacher Development Program (TDP) which tries to address weak teacher subject knowledge/ instructional practices for uplifting the current low pupil learning levels. However, it has been observed that the expansion of educational opportunities and overcrowded classes are hindering implementation of acquired intervention skills. So, this study used a descriptive survey design in a quantitative method, employing Linkert scale questionnaire items, to investigate evidence of teachers' use of acquired skills from the TDP training in their classroom instructions in Hadejia town of Jigawa state, Nigeria. Responses were interpreted using mean and SD to determine extent of implementing components of the three constructs under study, and a $p$ value to correlate the responses of the $\mathbf{1 5}$ administrators and that of the 81 teachers, who are the sample of the study, to find out if any significant differences existed between their views. Findings indicate that there are no significant differences between administrators' and teachers' responses on the implementation of the three constructs, but there exit some discrepancies about some variables under each construct. This finding can aid in-service teacher training decision making and modifications to ensure full implementation of acquired skills by TDP trained teachers.
\end{abstract}

Keywords-implementation; acquired training; teacher development program

\section{INTRODUCTION}

TDP is built on complementing and strengthening the work of Development Partners to support government to improve the quality of education provision. The programme commenced from 2013 to work till 2019 and is operating in six northern states of Nigeria- Jigawa, Kaduna, Kano, Katsina, Niger and Zamfara; to improve the skills of 66,000 teachers who are, in turn, expected to improve the learning outcomes of over 2.3 million students for every year they continue as teachers [1]. 665 teachers have received and participated in TDP training in Jigawa state. From this number, 96 teachers are from Hadejia local government education authority. 12 primary schools were selected by SUBEB and TDP to participate in the training and 8 teachers from each school (4 from cohort $1 \mathrm{~A}$ and 4 from cohort 1 B) have received training. Before intervention, TDP treatment school teachers were found to involve learners in positive interactions for only $24 \%$ of lesson time [2]. So, this paper examined the implementation of good pr actice by these TDP trained teachers to see if there is positive improvement in their instructional interactions with the learners

\section{LITERATURE REVIEW}

For success in providing education for all, teachers should have constant training and thorough supervisions [3] because they are very vital and essential for achieving such education [4]. But, the quality of Nigerian teachers is still a challenge because, they are poorly trained with about $70 \%$ in the north having below NCE trainings [5]. This necessitated directive actions to uplift teacher effectiveness.

The mandated minimum qualification for teachers in Nigeria is the Nigerian certificate in Education (NCE) and government has planned that unqualified ones be removed from the job [6]. Despite such giant strides to boost education, low subject knowledge and poor teaching still exists in Nigeria [7]. It has been found that teachers' inability to use proper teaching methods contributes in poor learning outcomes.

This is because, as Tata and Rabiu [8] stated, teachers sometimes hardly ponder on learners' level and background when employing methods for instructions. On the average teachers are found to involve pupils for about $25 \%$ of the lesson time even in child-centred and hands-on teaching practices that characterise effective teachers and classroom practice. By comparison, simply writing or reading mostly took up to $37 \%$ of lesson time [9]. 
Furthermore, research findings indicate that overcrowded classes due to expansion of educational prospects have made the former teacher centred methods persistent, with limited chances of using learnt training skills [10] which take learners' needs and temperaments into cognisance. Additionally, about $56 \%$ teachers in Jigawa state were found not qualified, and since learning the means of improving teachers' effectiveness is a constant critical aspect of sustainable educational improvements [11], the executive chairman of the Jigawa State Universal Basic Education Board (SUBEB), Alahji Salisu Zakari said that over 240 teachers are involved in training organized by the state government in collaboration with TDP to boost their productivity, [12]. Teachers in the state have been participating in development training for the past five years and should by this time have improved the learning outcomes of a substantial number of students. Though, sustainable improvement of teacher effectiveness is difficult in Nigeria, programmes concerned with their situations will likely succeed [11].

Nonetheless, potential barriers may exist when teachers cannot see the purpose of training. Requiring teachers to give up their limited time to learn new strategies is more productive if the teachers see the value in it. When they see no purpose for it, training may be non-productive as teachers may feel bored and/or overwhelmed [13]. Consequently, it is essential to investigate implementation of TDP learned training methods and skills of improvisations by teachers who have completed training and attended cluster meetings.

\section{METHODOLOGY}

The descriptive survey design was employed in this study because it helps to ensure the reliability and relevance of obtained information from a couple of groups on the actual implementation of the issue under investigation. [14], said descriptive research design helps to vividly explain and interpret a current condition. By using this design, data could be gathered on the past oneyear classroom instructional and pedagogical practices of the TDP trained teachers to determine implementation of acquired skills. Moreover, this type of design describes conditions or situations of variables under study as they exist in their natural settings and finds out status of a phenomenon by studying the population concerning variables from which the required information that can help in generalizing is acquired [15].

Hence, two sets of questionnaires with similar contents were constructed and administered to 15 TDP local government administrators and 84 teachers. So, questionnaires distributed for collecting data were 99. However, only 81 teachers returned their completed questionnaires. But, all the 15 members of the administrative group completed and returned theirs making the available number for data analysis to be 96 .

Data were statistically calculated and interpreted through descriptive analysis by using the mean/ SD, and $\mathrm{p}$ values to explain the extent of implementation per the responses of the two groups and determine their relationships respectively. Responses were collected in the form of Likert item data and presented in three tables each displaying the mean, SD and $\mathrm{p}$ values of responses in each item. Explanations of the values were then given under each table.

The use of comparative inference in the conduct of this research work assumed that since the administrative group constantly supervise the classroom instructions and cluster meetings (CMs) each term, there will be no disagreement concerning the implementation of learned training skills and methods. Equally, the population of the study comprises all the teachers under TDP training and the administrative group who plan, organise, facilitate, and oversee all training and implementation activities. Therefore, the study is limited to only TDP personnel and TDP trained teachers of Hadejia local government Education Authority in Jigawa state, Nigeria. Another limitation is that only 81 out of the 84 teachers returned their questionnaires; 3 female teachers misplaced theirs and due to limitation of time replacements were not given to them. Hence, 24 females and 57 male teachers participated in this research work.

The purpose of this study is to better understand the dynamics of teachers putting newly learned best practices into action, including what TDP pedagogical methods and materials they are currently using to enhance students' success and the questions guiding it are:

RQ1:Have teachers been using facilitative classroom language in their teaching?

RQ2: Have teachers been implementing learned methods and skills during instructions?

RQ3: Have teachers been improvising materials and using TDP resources as guides in their instructional plans?

The above questions will be supported with the following hypotheses:

H1. There is no significant deference between teachers' and administrators' responses on the use of appropriate classroom language during instructions.

H2. There is no significant deference between teachers' and administrators' responses on the implementation of learnt methods and skills during instructions.

H3. There is no significant deference between teachers' and administrators' responses on the improvisation of no cost/ low cost materials and use of TDP materials as guide during instructions. 


\section{FINDINGS AND DISCUSSIONS}

Findings are discussed against each research question and hypothesisusing tables

RQ1: Have teachers been using facilitative classroom language in their teaching?

TABLE 1. ANSWERS FOR QR1

\begin{tabular}{|c|l|l|l|l|l|l|}
\cline { 2 - 5 } \multicolumn{2}{c|}{} & \multicolumn{2}{l|}{ Teachers } & \multicolumn{2}{l|}{$\begin{array}{l}\text { Administra- } \\
\text { tors }\end{array}$} & \multicolumn{1}{l}{} \\
\hline 1 & Items & Mean & SD & Mean & SD & P \\
\hline & $\begin{array}{l}\text { Give instructions } \\
\text { with } \\
\text { understandable } \\
\text { language }\end{array}$ & 4.32 & 0.82 & 4.02 & 1.13 & 0.30 \\
\hline 2 & $\begin{array}{l}\text { Commend and } \\
\text { praise learners for } \\
\text { correct or relevant } \\
\text { responses }\end{array}$ & 4.60 & 0.56 & 4.32 & 0.56 & 0.07 \\
\hline 3 & $\begin{array}{l}\text { Avoid use of self- } \\
\text { esteem harming } \\
\text { utterances and } \\
\text { correct mistakes } \\
\text { with motivating } \\
\text { comments }\end{array}$ & 4.11 & 1.16 & 2.22 & 0.91 & 0.001 \\
\hline 4 & $\begin{array}{l}\text { Use advice instead } \\
\text { of reprimand } \\
\text { when correcting } \\
\text { behaviour }\end{array}$ & 4.41 & 0.51 & 2.03 & 0.65 & 0.001 \\
\hline Total & & & & & \\
\hline
\end{tabular}

On the implementation of learned effective classroom language, items 1 and 2 have means of 4.32 and 4.60 respectfully, indicating that teachers always use easy comprehensible language when giving instructions, and commend and praise learners' right answers. The SD 0.82 and 0.56 of the teachers show low dispersion of responses from the mean, while SD 1.13 of administrators shows high spread, and 0.56 of the second item shows a lesser spread from their mean.

For avoiding the use of language which can harm learners' self-esteem, teachers' responses to item 3 indicate that they mostly do that with a mean of 4.11 , and always use advice instead of reprimand when correcting learners' behaviours as indicated by a mean of 4.41 in item 4 . The spread of responses from the mean is 1.16 for item 3 showing a high dispersion from the mean, and 0.51 for item 4 , which indicates a moderate dispersion of responses from their mean value. In contrast, administrators' mean of 2.22 and 2.03 in items 3 and 4, and the spread of responses from the mean of 0.91 and 0.65 show that teachers still use language that can harm leaners' self-esteem.

RQ2: Have teachers been implementing learned methods and skills during instructions?
TABLE 2. ANSWERS FOR QR 2

\begin{tabular}{|c|c|c|c|c|c|c|}
\hline & \multicolumn{2}{|c|}{ Teachers } & \multicolumn{2}{|c|}{$\begin{array}{c}\text { Administra- } \\
\text { tors }\end{array}$} & \multirow[b]{2}{*}{$\mathrm{P}$} \\
\hline & Items & Mean & SD & Mean & SD & \\
\hline 5 & $\begin{array}{l}\text { Give individual, pair } \\
\text { and group tasks and } \\
\text { guide/ support } \\
\text { learners to do them }\end{array}$ & 4.35 & 0.80 & 4.25 & 4.64 & 0.98 \\
\hline 6 & $\begin{array}{l}\text { Encourage high- } \\
\text { level thinking, give } \\
\text { take-home } \\
\text { assignments and } \\
\text { provideinstant } \\
\text { feedback }\end{array}$ & 4.33 & 0.49 & 2.05 & 0.80 & 0.82 \\
\hline 7 & $\begin{array}{l}\text { Useinstructional } \\
\text { games, role play and } \\
\text { drama in my } \\
\text { instructions }\end{array}$ & 4.13 & 1.06 & 4.12 & 1.13 & $\begin{array}{l}0.00 \\
1\end{array}$ \\
\hline 8 & $\begin{array}{l}\text { Use chants, rhymes, } \\
\text { songs, and } \\
\text { storytelling in my } \\
\text { instructions }\end{array}$ & 2.14 & 1.28 & 1.76 & 0.63 & 0.33 \\
\hline & Total & & & & & $\begin{array}{l}0.53 \\
2\end{array}$ \\
\hline
\end{tabular}

Responses to item 5 indicate that teachers always use individual, pair, and peer tasks and support learners in executing them, because it has 4.35 and 4.25 as means for teachers and administrators respectfully. The SDs are 0.80 and 0.98 indicating not high dispersion between responses and their mean. Item 6 has a mean of 4.33 for teachers indicating that they always encourage elevated level thinking, give take-home assignments and provide instant feedback to learners' responses.The $\mathrm{SD}$ is 0.49 showing that the spread of scores from their mean is low. However, this is opposed to the administrators' views which show 2.05 mean. But instructional games, roleplay, and drama are mostly used during instructions by the teachers as indicated with a mean of 4,13 which agrees with the mean of 4.12 in the administrators' responses to item 7 . Responses to item 8 have a mean of 2.14 , indicating that teachers rarely use chants, rhymes, songs, and storytelling during instructions. Spread of the responses from their mean is high as indicated by an SD of 1.28. Both teachers and administrators agree that chants, rhymes, songs and story- telling are not well used.

RQ3: Have teachers been improvising materials and using TDP resources as guides in their instructional plans? 
TABLE 3. ANSWERS FOR QR 3

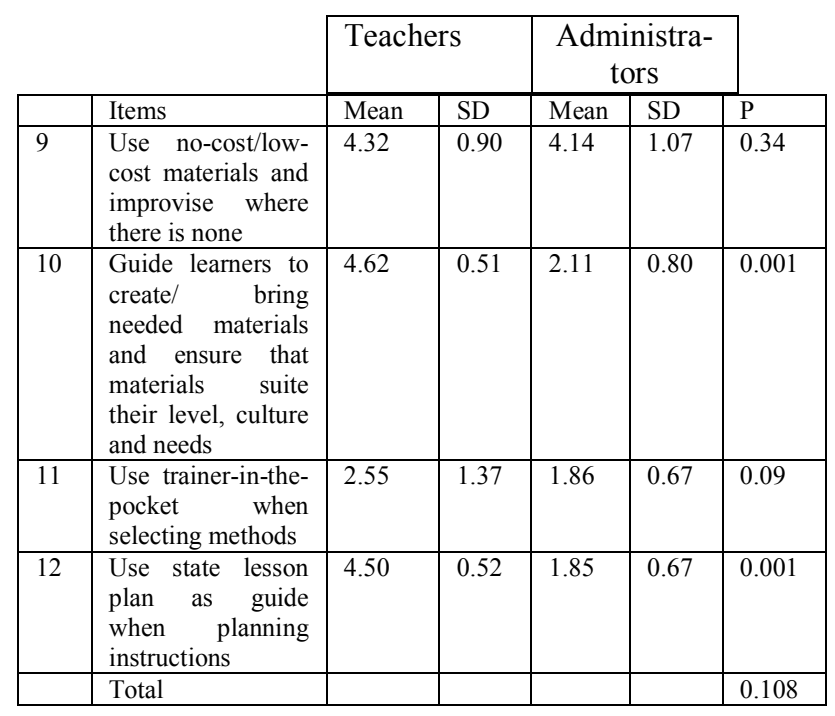

Table 3 shows that item 9 has a mean of 4.32/ SD of 0.90 for teachers and mean of 4.14/ SD of 1.07 for administrator, indicating that teachers use no-cost/ low-cost materials during instructions and improvise if there is none. However, the view of administrators of teachers rarely making learners create/bring materials from home or ensure the materials suit their levels is contradicted here, because teachers' responses to item 10 have a mean of 4.62 as against the administrators' mean of 2.11 and SD of 0.82 . Teachers' mean of $2.55 / \mathrm{SD}$ of 1.37 and administrators' mean of $1.86 / \mathrm{SD} 0.67$ in item 11 indicates that the trainer in the Pocket is rarely used as a guide for selecting instructional methods.

Teachers' responses to item 12 have a mean of 4.50 and SD of 0.52 , which indicates that teachers always use the TDP Jigawa state lesson plan as guide when planning instructions. But, the administrators' view is they rarely do so as is shown with a mean of 1.85 and an SD of 0.67.

H1. There is no significant deference between teachers' and administrators' responses on the use of appropriate classroom language during instructions.

Statistical analysis of the first two variables show $\mathrm{p}$ values of 0.30 and 0.07 respectively, indicating no significant deference between the responses of the administrators and the teachers. The last two variables have $p$ values of 0.001 each, which is less than 0.05 , thereby indicating statistical significant deference between the responses of the two groups. These controversial variables are very critical to promotion of learners' motivation because children with high self-esteem are inclined to have favourable views of themselves, successfully manage tasks and responsibilities at home and school, display appropriate compositions in communal situations, by acting responsibly toward others [16].

H2. There is no significant deference between teachers' and administrators' responses on the implementation of learnt methods and skills during instructions.
The first, second and fourth variables in this construct show $\mathrm{p}$ values of $0.98,0.82$ and 0.33 respectively, indicating no significant deference between the responses of the two groups. The third variable, however, have $p$ value of 0.001 , thereby indicating statistical significant deference between their responses.

H3. There is no significant deference between teachers' and administrators' responses on the improvisation of no cost/ low cost materials and use of TDP materials as guide during instructions.

Statistical analysis of the first and third variables show $\mathrm{p}$ values of 0.34 and 0.09 respectively, signifying no deference between the responses of the administrators and the teachers' because $p$ values are greater than 0.05 . The second and third variables, however, have $\mathrm{p}$ values of 0.001 each, which are less than 0.05 , thereby indicating statistical significant deference between the responses of administrators and teachers. On the contrary, the total $p$ value for the whole construct is 0.108 showing no significant difference.

The schools under study being in poverty areas which made the teachers to internalise the use of threat as a means of rectifying learners' wrong habits, may be the reason for the inferred discrepancies in the responses to the above investigated and analysed constructs. [17] believe that the admitted need to fill in the knowledge gaps notwithstanding, teachers' habits to inventions is mostly negative. Furthermore, there can be contradictions amid expectations and facts [18] where teachers may not always be unbiassed in self-assessments. What they perceive as their efficiency and deficiency may be the fact [19]. At times, some type of financial inducement is needed to make them implement innovation. [20] supported this view with the general invention of the pay-for-performance concept. Nonetheless, the $\mathrm{p}$ values for the entire responses of the three constructs are $0.098,0.532$ and 0.108 which show no significant differences for all three null hypotheses.

\section{IMPLICATIONS OF THE STUDY}

The findings of the research could help decisionmaking and TDP training modifications. SSVs could be intensified to ensure that administrators capture aspects that are not being implemented; like chants songs, rhymes, and storytelling. The work could also help state and local education Quality Assurance officials in their follow-up activities. It could help them decide which aspects of teacher effectiveness to emphasize in their quality reviews and plans. The results of this work could be used in national or state initiatives in their efforts to improve state and local government teacher training activities. Lastly, it can provide gaps for other researches; i.e. examining how SSVs are conducted, to find out if they have the potential of capturing every aspect of implementation by teachers in their instructions. 


\section{CONCLUSIONS}

To sum up, the mean values of data from both groups of respondents on items $1,2,5,7$, and 9 shows no significant difference between administrators' and teachers' responses. Disagreement in the mean values of both groups on the items $3,4,6,8,10,11$, and 12 are a bit wide, but not complete because, "always", "mostly" and "sometimes" denote existence. This might be why, when the $p$ for whole aspects were calculated, they showed no significant difference between the responses of the two groups.

Therefore, it can be concluded that there are no significant differences between administrators' and teachers' responses on the implementation of learnt classroom language, learnt methods and skills, improvisation of materials and use of TDP materials as guide. This conclusion indicates that, administrators' responses that point to teachers' reluctance to fully implement some components of the constructs under study did not show ineffectiveness on their part. This can be backed up with the assertion that most teachers were found to be more creative, innovative [2] and generate means to support struggling learners [21].

\section{ACKNOWLEDGMENT}

This research was carried out around September 2016 to January 2017 under the supervision of Dr Amrita Kaur of School of Education, Universti Utara Malaysia. Hence, the authors would like to acknowledge her support and guidance without which the work would not have been possible.

\section{REFERENCES}

[1] UNESCO. DFID'S Education programmes in Nigeria. Independent Commission for Aid Impact. 2012 Nov

[2] De S, Pettersson G, Morris R, Cameron S. Teacher Development Programme (TDP). Impact Evaluation of Output 1: In-Service Training, Final Baseline Technical Report, Volume I Results and Discussions. EDOREN, Abuja. 2016 June

[3] Amuchie AA, Asotibe N, Audu CT. An Appraisal of the Universal basic Education in Nigeria. Global Journal of Management and Business Research Administration and Management. 2013;13(11):17. Wilson G. Teachers' Challenges and Job Performance under the Universal Basic Education Scheme in Rivers State, Nigeria (20072015). Covenant University Journal of Politics and International Affairs. 2016 Jun 14;4(1).

[4] Wilson G. Teachers' Challenges and Job Performance under the Universal Basic Education Scheme in Rivers State, Nigeria (20072015). Covenant University Journal of Politics and International Affairs. 2016 Jun 14;4(1).

[5] Sanubi FA, Akpotu NE. The Nigeria education system and vision 20: 2020: A critical development planning perspective. International Journal of Educational Administration and Policy Studies. 2015 Mar 31;7(2):26-38

[6] Kalagbor LD, Agabi CO. Peace education and the Nigerian student: Panacea for student restiveness in the University system. International Journal of Educational Foundation and management. $2013 ; 1(2): 167-176$

[7] Kontagora HL, Azare GD. Producing effective teachers using Open and Distant Education (ODE): A case study of National Teachers' Institute (NTI) graduates in Nigeria. 2017

[8] Tata US, Rabiu UZ. The causes of poor performance in English among senior secondary school students in Dutse metropolis of
Jigawa state, Nigeria. Journal of research and method in education. 2014

[9] Stephi S. Teacher Development Programme In-Service Training Component Impact Evaluation 2014, Baseline Survey. Oxford Policy Management Ltd for DFID. 2016 Sep.

[10] Afework AA. An assessment of the implementation of continuous professional development program in selected secondary and preparatory schools of Dawuro zone. 2014 Unpublished MA Thesis

[11] MacAuslan I. Improving teachers: evaluating the TDP. Education Data Research and Evaluation in Nigeria EDOREN. 2015 Feb.

[12] Kura MZ. Nigeria: Jigawa Receives N1.2 Billion SUBEB Intervention.Leadership Newspaper 2015 Dec 5. Abuja. Retrieve from http://allafrica.com/stories/201512070071.html

[13] Christ T, Wang XC. Exploring a community of practice model for professional development to address challenges to classroom practices in early childhood. Journal of Early Childhood Teacher Education. 2013 Oct 1;34(4):350-73.

[14] Best JW, Kahn JV. Research in education: (10th ed.). Boston, Pearson education Inc 2006

[15] Ejifugha AU. Fundamentals of research in health education. Owerri: Africana FEP Publishers. 1998;106.

[16] Larkin R, Thyer BA. Evaluating cognitive-behavioral group counseling to improve elementary school students' self $\square$ esteem, self $\square$ control, and classroom behavior. Behavioral Interventions. 1999 Jul 1;14(3):147-61.

[17] Torff B, Sessions D. Teachers' attitudes about professional development in high-SES and low-SES communities. Learning Inquiry. 2009 Aug 1;3(2):67-77.

[18] Griffith SC, Conrad TL. Bridging the knowing and doing gap: The No Child Left Behind Act, race, and suburban school districts. Multicultural Review. 2008;17(3):97-8.

[19] Fessler R, Burke PJ. Systematic Appraisal of Teacher Performance: A Conceptual Supervision-Staff Development Model. Are You Doing Inquiry along These Lines?. Journal of Curriculum and Supervision. 1987;2(4):381-89.

[20] Yuan K, Le VN, McCaffrey DF, Marsh JA, Hamilton LS, Stecher BM, Springer MG. Incentive pay programs do not affect teacher motivation or reported practices: Results from three randomized studies. Educational Evaluation and Policy Analysis. 2013 Mar;35(1):3-22.

[21] Allsop T, Nnodu I, Jones S, Rai S, Watts M. Study of ESSPIN's support to capacity development in education in Nigeria. EDOREN for DFID. 2016 Jan. 